\title{
IMPROVED ALGORITHM FOR A DC SHUNT MOTOR USING DIFFERENT DEFFUZZIFICATION TECHNIQUES
}

\author{
A. N. Al-Husban \\ Al-Balqa Applied University, faculty for Engineering Technology, Amman- \\ Jordan
}

(Received December 31, 2005 Accepted March 26, 2006)

\begin{abstract}
This paper considers the fuzzy control of a non-linear dynamic system. The approach is known to be model-free and utilizes the field experience with running and supervising the process by human expertise. The advices given by the expert for proper running of these systems are given in the form of recipes full of linguistics. These linguistics can be turned into linguistic variables with limited sets of labels by the designer and to be the primitive seeds for what is called knowledge base. This base is kept in the memory of a computer unit. Assume that a running condition is given and has to be transferred into equivalent linguistic variables, in order to use the knowledge base and induce the output in a form of linguistic variables. Knowing that the linguistic variables is the same as fuzzy variables, the process of a fuzzy control can be stated as the three step procedure, a fuzzification stage, an inference stage, and finally a defuzzification stage, in which a crisp value is obtained for the process control input. The defuzzification stage is not unique and different techniques have been proposed in the literature. Starting from the centroid method up to the maximum principle method, the methods vary between themselves in complexity and time consumed by the computer unit. This, in turn, could result in different time responses for the given nonlinear dynamic systems. The paper concentrates on the effect of the defuzzification techniques on the transient response of a DC shunt motor taken as a model example of non-linear systems. A comparative study is given supported by computer simulation for each case.
\end{abstract}

\section{LIST OF SYMBOLS}

\begin{tabular}{llll} 
Ra, Rf & The armature and field resistance & TL & The load torque \\
La, Lf Ia, & The armature and field inductance & COA & Center of area \\
If & The armature and field current & MOM & Mean of medium \\
VT & The applied motor voltage & $\mu(\mathrm{k})$ & Membership degree \\
$\beta$ & The viscous friction & PM & Positive medium \\
$\varphi$ & The air gap flux & ZE & Zero \\
$\omega$ & The motor speed & NS & Negative small \\
$\mathrm{J}$ & The motor inertia & & \\
\hline
\end{tabular}




\section{INTRODUCTION}

During the past years, many control techniques have been developed for improving the performance of a DC motor $[1,2]$. The problem of controlling a DC shunt motor involves many practical problems, which may appear as a result of the continuous change of its field current. This means that the system equivalent mathematical model will be continuously changing and therefore one controller will not be sufficient to meet the different operating conditions. Due to the nonlinearities of various components of the systems, a linear model obtained by linearization around an operating point is usually adopted for the controller design. However, because of the inherent characteristics of changing loads, the system performance with controllers designed for a specific operating point will no longer be optimum [3, 4].

The fuzzy logic based speed controller for a DC shunt motor is presented over the whole range of operation. Such a controller needs neither a nonlinear nor a linear mathematical model. The objective of such controller is to restore the motor speed through eliminating the speed error arising due to load changes. The only measurements required for the control design are only the output error and the change in the output error [5-8].

This paper considers the fuzzy control of a non-linear dynamic system. The approach is known to be model-free and utilizes the field experience with running and supervising the process by human expertise. The advices given by the expert for proper running of these systems are given in the form of recipes full of linguistics. These linguistics can be turned into linguistic variables with limited sets of labels by the designer and to be the primitive seeds for what is called knowledge base. This base is kept in the memory of a computer unit.

Assume that a running condition is given and you have to transfer the linguistic variables into equivalent linguistic variables, in order to use the knowledge base and induce the output in a form of a linguistic variable. Knowing that the linguistic variables are the same as fuzzy variables, the process of a fuzzy control can be stated as the three step procedure, a fuzzification stage, an inference stage and finally a defuzzification stage, by which a crisp single value is obtained for the process control input. the defuzzification stage is not unique and different techniques have been proposed in the literature. Starting from the centroid method up to the maximum principle one, the methods vary between themselves in complexity and time consumed by the computer unit. This, in turn, could result in different time responses for the given nonlinear dynamic systems.

The paper concentrates on the effect of the defuzzification techniques on the transient response of a DC shunt motor taken as a model example for non-linear systems. A comparative study is given supported by computer simulations for each case.

\section{SYSTEM DESCRIPTION}

The system to be considered in this study consists of a DC shunt motor. In the following part, the mathematical model of each component will be given pointing out all nonlinearities and approximations that are usually neglected when using conventional techniques $[5,7,9,10]$. 


\subsection{Shunt Motor [3]}

The mathematical model of the DC shunt motor is a nonlinear third order one expressed as follows:

$$
\begin{aligned}
& \mathrm{V}_{\mathrm{T}}=\mathrm{R}_{\mathrm{a}} \mathrm{I}_{\mathrm{a}}+\mathrm{L}_{\mathrm{a}} \frac{\mathrm{dI} \mathrm{a}_{\mathrm{a}}}{\mathrm{dt}}+\mathrm{k}_{\phi} \omega \mathrm{I}_{\mathrm{f}} \\
& \mathrm{V}_{\mathrm{T}}=\mathrm{R}_{\mathrm{f}} \mathrm{I}_{\mathrm{f}}+\mathrm{L}_{\mathrm{f}} \frac{\mathrm{dI}_{\mathrm{f}}}{\mathrm{dt}} \\
& \mathrm{k}_{\phi} \omega \mathrm{I}_{\mathrm{a}}=\mathrm{J} \frac{\mathrm{d} \omega}{\mathrm{dt}}+\beta \omega+\mathrm{T}_{\mathrm{L}}
\end{aligned}
$$

It is worth noting that the term $k_{\phi}$ is a varying gain representing the relation between the field current $\mathrm{I}_{\mathrm{f}}$ and the airgap flux $\varphi$. In addition, the bilinearity in eqn. (1) represents a nonlinear quantity due to inherent magnetic saturation characteristics.

\section{FUZZY LOGIC CONTROLLER (FLC)}

The FLC controller belongs to a general class of fuzzy logic system $[11,14]$ in which control variables are transformed into linguistic variables and manipulated by what is known as the fuzzy inference engine. This engine reasons a set of linguistic rules constituting the system knowledge or expertise base to result in the most proper action for a given set of inputs. These rules are derived from the knowledge of experts with substantial experience in the DC drive-systems and machine control. In the following part, the architecture of such a controller is thoroughly examined.

\subsection{Fuzzy System Architecture}

The main objective of the fuzzy control scheme is to replace an expert human operator with a fuzzy rule-based control system [5]. The fuzzy-logic control (FLC) comprises three stages; namely the fuzzifier, the rule-base and the defuzzifier. Figure 1 shows how the three stages are connected.

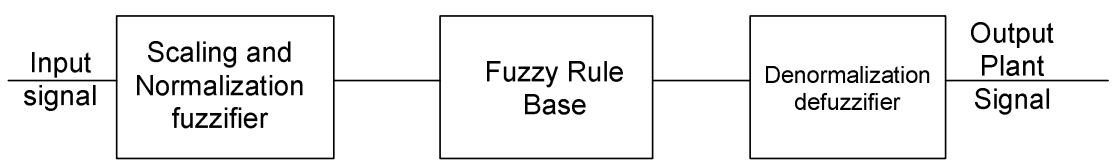

Fig. 1: The basic configuration of a Fuzzy logic controller.

This proposed FLC is installed as shown in Fig. 2.

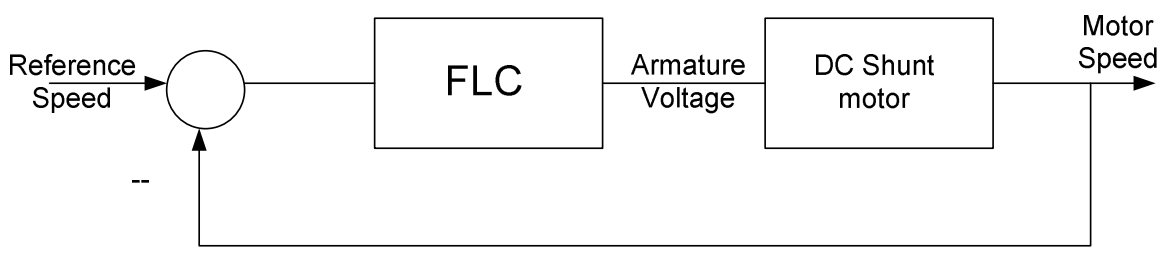

Fig. 2: FLC block diagram. 
The fuzzy logic controller proceeds as follows to evaluate the desired output signal, as shown. in Figure 3. Firstly the input variables are normalized. Then the membership function of the fuzzy logic controller output signal is determined by linguistic codes. Finally, the numerical value of the FLC output signal corresponding to a specific linguistic code is determined.

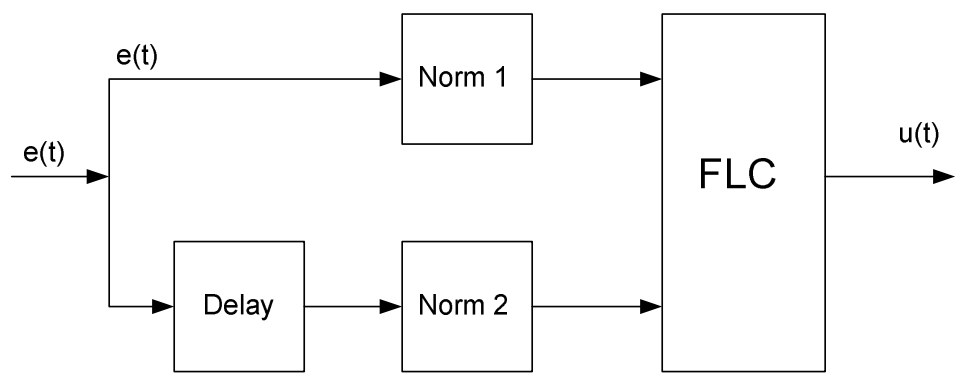

Fig. 3: The internal structure of the FLC.

\subsection{Fuzzy Control Algorithm}

To provide an acceptable overall performance, the FLC system must have a quick response with small steady state error, therefore, the proposed rule base depends on the following concepts:

- $\quad$ The fuzzy controller maintains the output value when the output value is a set value and the error change is zero.

- Depending on the magnitude and sign of the speed error and speed error change, the output value will return to the set value.

Whenever a departure between the two values exists, the error (e) and the error change $(\Delta \mathrm{e})$ are defined as the difference between the set-point value $\Delta \omega_{r}^{o}(\mathrm{k})$ and the current output value $\Delta \omega_{c}^{m}(k)$.

$$
\begin{aligned}
\mathrm{e}(\mathrm{k}) & =\Delta \omega_{\mathrm{r}}^{\mathrm{o}}(\mathrm{k})-\Delta \omega_{\mathrm{c}}^{\mathrm{m}}(\mathrm{k}) \\
\Delta \mathrm{e}(\mathrm{k}) & =\mathrm{e}(\mathrm{k})-\mathrm{e}(\mathrm{k}-1) \\
& =\Delta \omega_{\mathrm{c}}^{\mathrm{m}}(\mathrm{k}-1)-\Delta \omega_{\mathrm{c}}^{\mathrm{m}}(\mathrm{k})
\end{aligned}
$$

That is,

$\Delta \omega_{r}^{o}(k)=\Delta \omega_{r}^{o}(k-1)$

Where:

$\Delta \omega_{r}^{o}(k)$ is the reference speed at the $\mathrm{k}^{\text {th }}$ sampling interval and $\mathrm{e}(\mathrm{k})$ is the error signal.

$\Delta \omega_{c}^{m}(k) \quad$ is the speed signal at the $\mathrm{k}^{\text {th }}$ sampling interval.

$\Delta \mathrm{e}(\mathrm{k}) \quad$ is the error change signal. 
The workable range is divided into intervals. These intervals are named for example: positive, zero and negative. These names for the intervals are called labels.

The above three labels, the input variables and the output of the fuzzy controller, are related as shown in Table 1; where the error is represented by its labels in the first row and the change error is represented in the first column. However, the output would be inside each cell.

Table 1: Rule table.

\begin{tabular}{|c|c|c|c|}
\hline$\Delta \mathrm{e} / \mathrm{e}$ & $\mathrm{P}$ & $\mathrm{Z}$ & $\mathrm{N}$ \\
\hline $\mathrm{P}$ & & $\mathrm{P}$ & \\
\hline $\mathrm{Z}$ & & $\mathrm{Z}$ & \\
\hline $\mathrm{N}$ & & $\mathrm{N}$ & \\
\hline
\end{tabular}

Then the control variable should be changed. The control law can be formalized as:

$$
\Delta U(k)=F(e(k), \Delta e(k))
$$

To express the fuzzy logic input in linguistic codes (fuzzy labels) $\mathrm{P}, \mathrm{Z}$ and $\mathrm{N}$, the measured fuzzy logic controller input $\mathrm{e}(\mathrm{k})$ and $\Delta \mathrm{e}(\mathrm{k})$ are first normalized based on the desired frequency of the multi-area under control as:

$$
\mathrm{e}_{\mathrm{n}}(\mathrm{k})=\frac{\mathrm{e}(\mathrm{k})}{\mathrm{w}_{\mathrm{r}}^{\mathrm{o}}} \quad, \quad \Delta \mathrm{e}_{\mathrm{n}}(\mathrm{k})=\frac{\Delta \mathrm{e}(\mathrm{k})}{\mathrm{w}_{\mathrm{r}}^{\mathrm{o}}}
$$

membership function of error, Where $w_{r}^{o}$ is a normalizing factor.

Many types of membership function exist. In this paper, the triangularshaped functions shown in Figure 4,are chosen owing to their simplicity as well as being closer to human thinking.

The working range of error and change of error are normalized and divided equally by a number of divisions equal to the proposed number of labels. On the extremes, the trapezoidal forms are used instead of triangular forms to be very close to the real life cases.

The membership functions for these two variables are as shown in Figure 4.
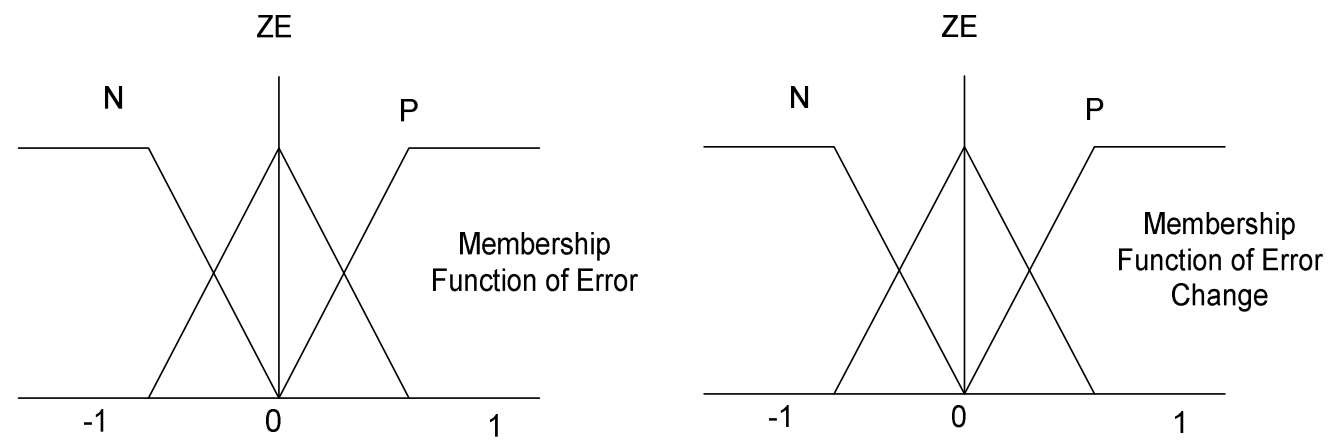

Fig. 4: The membership function. 


\section{DEFUZZFICATION TECHNIQUES}

Defuzzification is a procedure to find the crisp element, based upon the knowledge that the fuzzy value of the output variable $\mathrm{Z}$ is $\mathrm{F}$ where,

$$
\mathrm{Z}=\text { defuzzifier }(\mathrm{F}(\mathrm{z}))
$$

Where $F(z)$ is a fuzzy set. $Z$ is a crisp output, and the defuzzifier represents a defuzzification operator.

Basically, defuzzification is a mapping function from a space of fuzzy control actions defined over an output inverse of discourse into a space of nonfuzzy control actions. It is employed because in many-practical application a crisp control action is required. The commonly used defuzzification methods are the mean of maxima (MOM) and the center of area (COA) methods. Alternative defuzzification methods that are widely used in practical applications can be found in $[8,11,12]$.

\subsection{Max- Membership Method}

The max criterion produces the point at which the possibility distribution of the control action reaches a maximum value, it is also known as the height method. This scheme is limited to peaked output functions as here

$$
\mu\left(Z^{*}\right) \geq \mu(Z) \quad \forall \quad z \in Z
$$

And $\mathrm{Z}^{*}$ is the required crisp output.

\section{2 Centroid Method}

This procedure (also called center of area or center of gravity) is the most prevalent and physically appealing of all the defuzzification methods, it is given by

$$
\mathrm{Z}_{\mathrm{COA}}^{*}=\frac{\sum_{\mathrm{j}=1}^{\mathrm{n}} \mu\left(\mathrm{z}_{\mathrm{j}}\right) \cdot \mathrm{z}_{\mathrm{j}}}{\sum_{\mathrm{j}=1}^{\mathrm{n}} \mu\left(\mathrm{z}_{\mathrm{j}}\right)}
$$

Where $\mathrm{n}$ is the number of quantization levels of the output.

\subsection{Weighted Average Method}

This method is only valid for symmetrical output membership functions. It is formed by weighing each membership function in the output by its respective maximum membership value, it is given by:

$$
\mathrm{Z}^{*}=\frac{\sum_{\mathrm{j}=1}^{\mathrm{n}} \mu(\overline{\mathrm{z}}) \cdot \overline{\mathrm{z}}}{\sum_{\mathrm{j}=1}^{\mathrm{n}} \mu(\overline{\mathrm{z}})}
$$

Where $\bar{Z}$ is the mean of the respective maximum value. 


\subsection{Mean-Max Membership (MOM)}

This method (also called middle-of-maxima) is closely related to the first method, except that the locations of the maximum membership can be non-unique. This method is given by:

$Z^{*}=\frac{\sum_{j=1}^{n} \bar{Z}_{j}}{n}$

This MOM strategy generates a control action which represents the mean value of all local control actions whose membership functions reach the maximum.

\subsection{The Proposed Algorithm}

The proposed approach to develop a fuzzy logic control consists of four stages:

Stage (1): Calculate the degree of firing

$$
\tau_{\mathrm{i}}=\mu_{\mathrm{i}}(\mathrm{e}(\mathrm{k})) \wedge \mu_{\mathrm{i}}(\Delta \mathrm{e}(\mathrm{k}))
$$

Stage (2): Find the output fuzzy set

$$
\mathrm{F}_{\mathrm{i}}(\Delta \mathrm{u}(\mathrm{k}))=\tau_{\mathrm{i}} \wedge \mu_{\mathrm{i}}(\mathrm{u}(\mathrm{k}))
$$

Stage (3): Find the overall system output

$$
\mathrm{F}(\Delta \mathrm{u}(\mathrm{k}))=\underset{\mathrm{i}}{\mathrm{v}} \mathrm{F}_{\mathrm{i}}(\Delta \mathrm{u}(\mathrm{k}))
$$

Stage (4): Find the crisp output using any defuzzification methods.

\section{NUMERICAL EXAMPLE}

In the following part, the data for a $4 \mathrm{~kW} / 220 \mathrm{~V} / 1450 \mathrm{rpm}$, DC shunt motor are given $[4,8]$

$\operatorname{Ra}=1 \Omega$

$\mathrm{Rf}=338 \Omega$,

$\beta=0.0184 \mathrm{Nm} / \mathrm{rad} / \mathrm{sec}$

$\mathrm{K}=2.2088 \mathrm{~V} / \mathrm{amp} . \mathrm{rad} / \mathrm{sec}$.

$\mathrm{La}=5 \mathrm{mH}$

$\mathrm{Lf}=5 \mathrm{mH}$

$\mathrm{J}=0.05 \mathrm{Kg} \cdot \mathrm{m} 2$

Hardware: 386-AT computer

Software: The program is written using QB- language

The proposed defuzzification techniques have confirmed the effectiveness of the proposed controller in the presence of system nonlinearities. The results shown in Figure 5, indicate the closed-loop response of the DC shunt motor for different defuzzification techniques. 


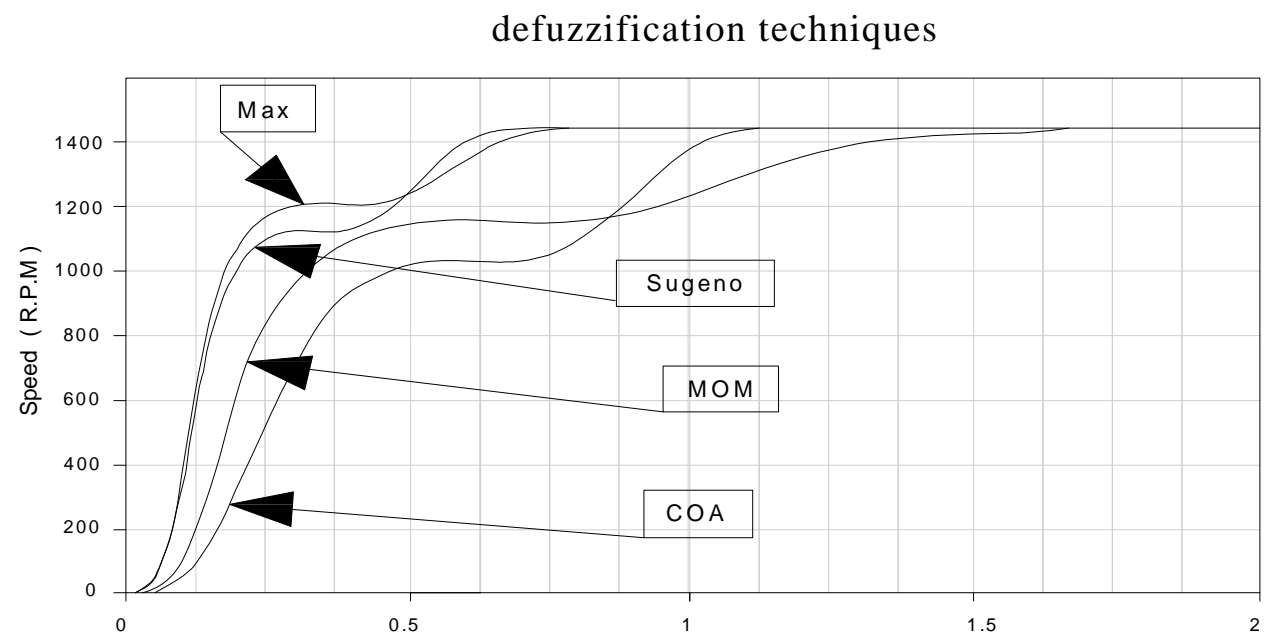

Fig. 5: System response with defuzzification techniques.

It is clear that the Max technique results in a faster response during transients compared with the Weighted Average (Sugeno), COA and MOM techniques. On the contrary to that, the MAX and Sugeno result in a smaller steady-state error.

Steady state error for each case :

$\begin{array}{llll}\text { MAX } & \text { ess }=3 \% & \text { RISE TIME } & \mathrm{Tr}=0.6 \mathrm{Sec} \\ \text { SUGENO } & \text { ess }=2.8 \% & \text { RISE TIME } & \mathrm{Tr}=0.6 \mathrm{Sec} \\ \text { MOM } & \text { ess }=4.5 \% & \text { RISE TIME } & \mathrm{Tr}=0.6 \mathrm{Sec} \\ \text { COA } & \text { ess }=5 \% & \text { RISE TIME } & \mathrm{Tr}=0.6 \mathrm{Sec}\end{array}$

This transient response is taken for a speed of $1400 \mathrm{rpm}$ and not the rated speed of $1450 \mathrm{rpm}$.

Each response is taken for one case of number of labels (3 labels) or 9 rules. We fixed the number of labels or rules to show the effect of defuzzification methods.

We confirmed this result in the control lab.

\section{CONCLUSION}

This paper has studied the effect of converting fuzzy forms into crisp forms, a process called defuzzification. Defuzzification is a natural and necessary process; there is an analogous form of defuzzification in mathematics where we solved a complicated problem in the complete MOM. It involves less computation than the center of sums; computational simplicity. The results depict a validation of these techniques to control the DC shunt motor, and the results validate that the motor dynamic response is free speed over-shoot. 


\section{REFERENCES}

[1] I. H. Khalifa and E. A. Sarhan. "A Knowledge-Based Speed Control of Separate Excited DC Motor". Egyptian Computer Science Journal. Vol. 11., No. 1, 1980.

[2] I. H. Khalifa and S. A. Ibrahim. "Robust Adaptive Control for High Performance DC Drives". 15th. International Congress for Statistics. Ain shams university. March 1990.

[3] I. H. Khalifa and A. El-Husban. "Feedback Linearization for DC Shunt Motor Control". Proc. oftheICECS'95.

[4] I. H. Khalifa and E.A.Sarhan. "Optimal Modeling of a DC shunt motor using Artificial Neural Networks", Proc. of the 18th IFIP TC7 Conference on System Modeling and Optimization. Detroit. MI. 1997.

[5] I. H. Khalifa, M.H.Saleh. and A.H.El-Assal. "A Fuzzy Logic Speed Control A DC Shunt Motor". MEPCON'97. Alex . Egypt. 1997.

[6] I. H. Khalifa, A. H. El-Assal and M. H. Saleh. "Fuzzy Logic Controller for Multi-Area Load Frequency Control of Electric Power Systems". Proc. of the 6th International Conference on Computer Theory and Applications. ICCTA'96. pp. 31-35. Sep. 1996.

[7] I. H. Khalifa, A. H. El-Assal and M. H. Saleh. ".An Adaptive Fuzzy Controller To Improve System Performance". Proc. of the 6 th International Conference on Computer Theory and Applications. ICCTA'97.. Alexandria. Egypt. Sep. 1997.

[8] I. H Khalifa. A. H. El-Assal and M. H. Saleh. "A Conjugate Gradient Technique For Optimal Fuzzy Logic Control of Highly Complex Dynamic System". Proc. of the 7th International Conference on Computer Theory and Applications. ICCTA'97. Alexandria. Egypt. Sep. 1997.

[9] I. Boldea and S. A. Nasar. "Electric Machines Dynamics". Macmillan Publishing Company. New York. 1986.

[10] P. C. Krause. "Analysis of Electric Machinery". McGraw-Hill Book Company. New York. 1986.

[11] T. J. Ross." Fuzzy Logic with Engineering Application" McGraw-Hill. Inc.. 1995.

[12] R. R. Yager and D. P. Filev. "Essentials of fuzzy modeling and control". John Wiley \& Sons, New York. 1994.

[13] W. Pedrycz. "Fuzzy Control and Fuzzy Systems". John Wiley \& Sons. New York . 1992.

[14] T. Tero. K. Asai, and M. Sugeno, "Fuzzy Systems Theory and Its Applications". Academic Press. London 1991.

[15] International GI-Workshop Fuzzy-Neuro Systems '98 - Computational Intelligence .

[16] IEEE International Conference on Fuzzy Systems (FUZZ-IEEE'98).

[17] International GI-Workshop Fuzzy-Neuro Systems '98 - Computational Intelligence - 18 - 20 March 1998, Munich.

[18] IEEE International Conference on Neural Networks (ICNN'97).

[19] The Sixth IEEE International Conference on Fuzzy Systems, Conference on Computational Intelligence for Financial Engineering, New York City, 1997.

[20] Pablo Carbonell, Fuzzy Gain Scheduling Control of Switch-mode DC/DC Converters, 2003. 
[21] D. Hissel, P. Maussion, J. Faucher, Speed Ripples Reduction of a Nonlinear Loaded Synchronous Motor Through Fuzzy Algorithms Computation, Institut National Polytechnique de Toulouse, Ecole Nationale Superieure EEIH, Toulouse Codex 7, France, 2004.

[22] Abdullah Miloudi, Azeddine Draou, Variable Gain PI Speed Control of a Direct Tourque Neuro Fuzzy Controlled Induction Motor Drive, 2003.

[23] A. F. Stronach, P.Vas, M. Neuroth, Development of Neuro-fuzzy Speed Estimators for Implementation in High-performance Electromechanical Drivers, University of Aberdeen, UK, 2004.

\section{خوارزمية محسنة لمحرك تيار مستمر من نوع التوازي

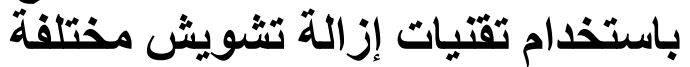

\author{
د.احمد نزال الحسبان \\ ص.ب. (15008)/ماركا ـ عمان ـ الأردن التطن
} \\ كلية الهندسة التكنولوجية / جامعة البلقاء التطبيقية}

تتناول هذه الورقة موضوع التحكم المشوش بالأنظمـة الديناميكيـة غير الخطيـة. وهذا المنهج

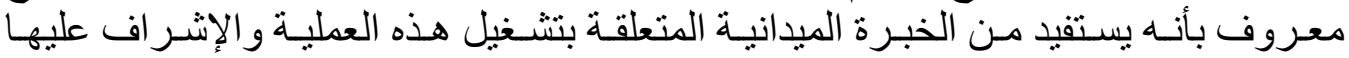

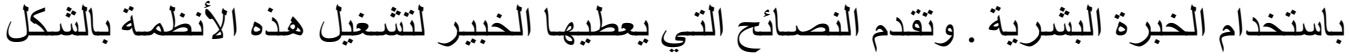

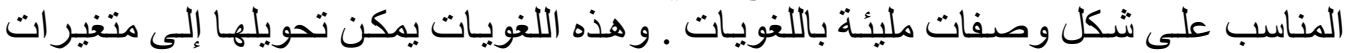

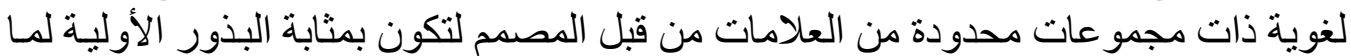
يعرف باسم القاعدة المعرفية ـ و هذه القاعدة يتم حفظها في ذاكرة وحدة وحدة حاسوبية.

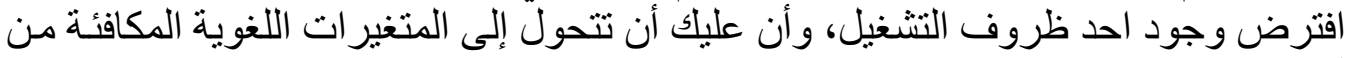
أجل استخدام القاعدة المعرفية و إحداث مخر ج على شكل متغير ات لغوية.

وبمعرفة أن المتغيرات اللغوية هي ذاتها متغير ات مشوشة، فانه بمكن إنشاء عملية تحكم مبنية

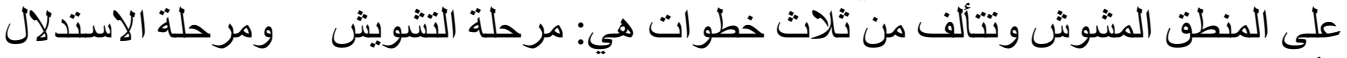
و أخير ا مرحلة إز الة التشويش، التي يتم فيها الحصول على قيمة و اضحة لاستخدامها كإثـارة مدخل لعملية التحكم.

إن عملية إز الة التشويش ليست عملية متفردة، فقد تم اقتر اح تقنيات مختلفة في الأدبيات ذات العلاقة.

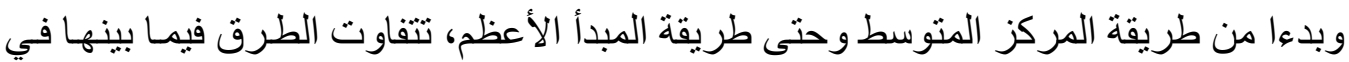

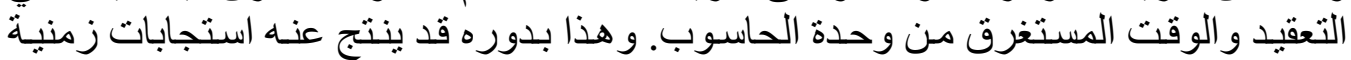

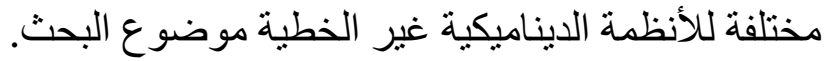

تركز هذه الدر استة على اثر تقنية إز الة التشويش على الاستجابة العـابرة لمحرك تك تبار مستمر

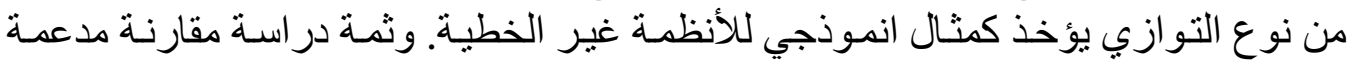
بمحاكاة حاسوبية لكل حالة. 